\title{
THE STATE AND PROBLEMS OF SERBIAN AGRICULTURE
}

\author{
Semir Vehapi ${ }^{1}$, Zenaida Šabotic ${ }^{2}$
}

\begin{abstract}
Summary
Modern agriculture includes the process of building a new economic activity based on efficiency, competitiveness, intensity and marketability. The process of transition of Serbian agriculture to market conditions is long and difficult. In this study the authors identify the most important problems of this process: unfavourable ownership structure and low productivity, the ineffectiveness of the agrarian and economic policy, the slow development of support institutions and legislative framework, and unsuccessful privatization in agriculture. We are dealing with a number of chronic problems that seriously threaten the development of agriculture and hinder the implementation of transition reforms. The authors propose measures and activities for achieving a transition shift in this strategically important economic branch for Serbia.
\end{abstract}

Key words: agriculture, ownership structure, agricultural policy, privatization, Republic of Serbia.

JEL: $Q 13, Q 18$

\section{Introduction}

Agriculture is the most important economic activity in the Republic of Serbia, which engages over a third of the working population, generates nearly $40 \%$ of the gross added value and makes up $23 \%$ of the overall Serbian export. It is only sector in the Serbian economy with a positive foreign trade balance (Maslac, 2013). During 2013, Serbia has created the highest surplus with the achieved value of 927.1 million EUR (Ministry of Agriculture, Forestry and Water Management, MAFWM, 2014). However, the contribution of agriculture to the overall economic development of Serbia is significantly limited by the many problems that it faces. An entire array of problems incurred as a result of restrictions in the period of central planning, difficulties in terms of development over the past twenty years, and the problems related to adapting to the market economy.

1 Assistant, State University of Novi Pazar, Department of Economic Science (office no. 23), Vuka Karadzica Street bb, 36300 Novi Pazar, Republic of Serbia, Phone: +381 638618381 , E-mail: semir.vehapi@gmail.com

2 Assistant, State University of Novi Pazar, Department of Economic Science (office no. 23), Vuka Karadzica Street bb, 36300 Novi Pazar, Republic of Serbia, Phone: +381 63506 146, e-mail: zenaida.šabotić@gmail.com

EP 2015 (62) 1 (245-257) 
Modern agriculture is the process of building new economic activities based on efficiency, competitiveness, intensity and marketability. The process of transition of Serbian agriculture to market conditions has been long and difficult. The transition of agriculture in the Republic of Serbia is over and includes two phases: the first phase that took place during the 1990s, and the second phase that began after the year 2000. The actual effects of both phases are unfavourable. In this paper, we analysed the effects of the second phase, as well as the key issues that contributed to the failure of the transitional reforms in this area. Only by taking into consideration the mistakes from the past can police that are likely to be effective in the future be made.

\section{Research goal, methodology and date sources}

A detailed analysis of the development problems of Serbian agriculture will contribute to a better understanding of their causes and the acceptance of appropriate measures and actions needed to address them, which is the main goal of the current research. In realizing such a research goal, we started from the following hypotheses: (1) Serbia possesses a significant natural potential for a more effective development of agricultural production; and (2) the three main problems in the second phase of agricultural transition are the ineffective agricultural and economic policies, the unfavourable structure of ownership, and the unsuccessful privatization. In order to prove the aforementioned hypothesis, the methods used included a descriptive analysis and a comparison. A descriptive analysis was use to gain insight into the relations and regularities in Serbian agriculture. At the same time, the agricultural sector is studied in a broader context which incorporates both the economy and society. A comparison is made between Serbia and other European countries, in order for us to identify any similarities and differences in the investigated phenomena, which could be important for the development of agriculture.

As a starting point for making judgments about the goal of this research, data from official statistical reports, source documents, and information obtained from relevant national and foreign sources were used. In addition, local authors who deal with these issues were also consulted.

\section{Research results and discussion}

\section{Indicators of production and the state of agriculture}

The Republic of Serbia has great potential in the sector of agricultural production due to favourable climatic conditions, good natural soil characteristics and available water resources, but this potential is not fully utilized. It is recognized as an economic sector that can produce more value than it does now and contribute to the overall economic development of the country in all municipal and regional strategies, and is defined as one of the main strategic direction of development (MAFWM, 2012, p. 4). 
Table 1. Capacities of Agricultural Production in the Republic of Serbia (in 000)

\begin{tabular}{|l|c|c|c|c|c|c|c|}
\hline Indicator & $\mathbf{2 0 0 6}$ & $\mathbf{2 0 0 7}$ & $\mathbf{2 0 0 8}$ & $\mathbf{2 0 0 9}$ & $\mathbf{2 0 1 0}$ & $\mathbf{2 0 1 1}$ & $\mathbf{2 0 1 2}$ \\
\hline Agricultural area(ha) & 5.105 & 5.092 & 5.093 & 5.097 & 5.092 & 5.096 & 5.092 \\
\hline Cultivable area(ha) & 4.228 & 4.218 & 4.222 & 4.226 & 4.216 & 4.211 & 4.215 \\
\hline Arable fields and gardens (ha) & 3.318 & 3.299 & 3.303 & 3.301 & 3.295 & 3.294 & 3.282 \\
\hline Orchards (ha) & 238 & 240 & 241 & 241 & 240 & 240 & 238 \\
\hline Vineyards (ha) & 62 & 59 & 58 & 58 & 57 & 56 & 54 \\
\hline Meadows(ha) & 610 & 620 & 620 & 626 & 624 & 621 & 641 \\
\hline Pastures(ha) & 838 & 835 & 833 & 834 & 836 & 845 & 837 \\
\hline Pools, reed tracts and fishponds (ha) & 39 & 39 & 38 & 39 & 40 & 40 & 40 \\
\hline Number of livestock units & 1.632 & 1.574 & 1.551 & 1.516 & 1.452 & 1.422 & 1.437 \\
\hline $\begin{array}{l}\text { Economically active population in } \\
\text { agricultural (Share in total economically } \\
\text { active population, \%) }\end{array}$ & $15,3 \%$ & $14,7 \%$ & $14,0 \%$ & $13,4 \%$ & $12,8 \%$ & $12,3 \%$ & $11,7 \%$ \\
\hline
\end{tabular}

Source: based on data from Food and Agriculture Organization Corporate Statistical Database (FAOSTAT) for certain years, and Statistical Office of the Republic of Serbia (2010, 2013, 2013a).

Note: Cultivable area consists of arable fields and gardens, orchards, vineyards and meadows.

Based on the data presented in Table 1, it is possible to conclude that Serbia has a comparative advantage in agriculture because it has agricultural and cultivable land as well as a considerable number of livestock units. The overall utilized agricultural area in Serbia is 5.092.000 hectares (ha), which is 57,6\% of its territory. Of those, 4.215 .000 ha or as much as $82,8 \%$ is cultivable area, which is above the European standards. Arable fields and gardens make up $64,5 \%$ of the overall agriculture area, pastures $16,4 \%$, meadows $12,6 \%$, orchards $4,7 \%$, vineyards $1,1 \%$ and pools, tracts and fishponds make up $0,8 \%$. The number of livestock units per hectare of agricultural land, indicate the degree of a country's agricultural development (Petrović, 2005; Petrović et al., 2011). Serbia has about 1.437 .000 livestock units or 28,2 per 100 ha of agricultural land. A more convincing indicator is the share of economically active agricultural population in the overall economically active population, which, with its $11.7 \%$, classifies Serbia as one of the leading European countries in this respect.

However, Serbia apparently does not exploit all of the natural wealth that it possesses to the fullest capacity. The best evidence of this includes the frequent fluctuations in the movement of agricultural production. For example, in the period from 2000 to 2012 , the physical volume of agricultural production increased only during five $(2001,2004$, 2008, 2009, 2011, see in Graph 1) of the thirteen years. The growth rate of agricultural production is unstable and mostly negative. There is a set of problems that affect Serbian agriculture, and which lead to significantly slower growth in production, as compared to the available resources. This paper analyses some of these major problems. 
Graph 1. Trends in Agricultural Production, the Republic of Serbia (2000-2012)

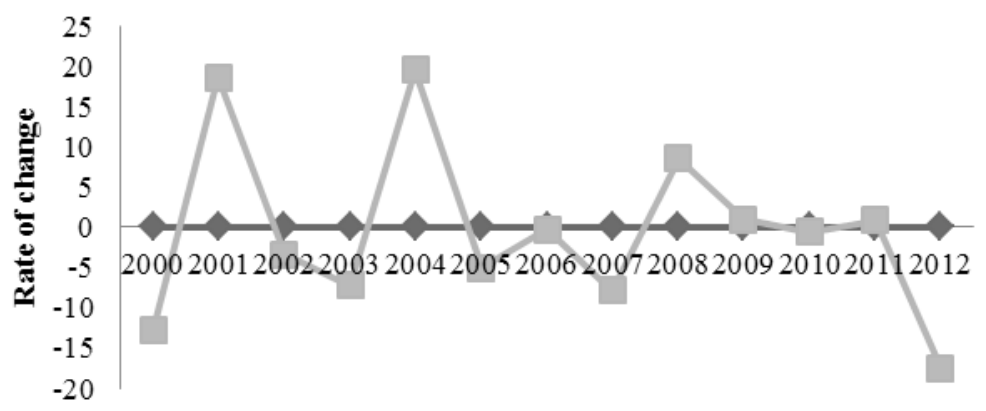

Source: authors' own design based on data from the Statistical Office of the Republic of Serbia (2010, 2013).

\section{Unfavourable Ownership Structure and Low Productivity}

Serbian agriculture is traditionally characterized by an unfavourable ownership structure, which is very typical for family holdings, as well as the predominant ones, dominant influence its overall development. The development of these holdings has long been hampered by various measures of agricultural policy, including limiting the size of land property whose size changed until its abolition (the measure was finally abolished in 1992). However, the ownership structure of Serbian agriculture still continues to be dominated by petty commodity production on small holdings. The transition has not managed to solve this problem.

Table 2. Ownership structure of agricultural holdings

\begin{tabular}{|l|r|r|r|r|r|r|}
\hline $\begin{array}{c}\text { Agricultural } \\
\text { area (ha) }\end{array}$ & $\begin{array}{c}\text { Serbia } \\
\text { (2012) }\end{array}$ & $\begin{array}{c}\text { Luxembourg } \\
\mathbf{( 2 0 1 0 )}\end{array}$ & $\begin{array}{c}\text { Netherlands } \\
\mathbf{( 2 0 1 0 )}\end{array}$ & $\begin{array}{c}\text { Denmark } \\
\mathbf{( 2 0 1 0 )}\end{array}$ & $\begin{array}{c}\text { France } \\
\mathbf{( 2 0 1 0 )}\end{array}$ & $\begin{array}{c}\text { Great } \\
\text { Britain } \\
(\mathbf{2 0 1 0})\end{array}$ \\
\hline $0-5$ & $77,7 \%$ & $17,2 \%$ & $29,2 \%$ & $4,8 \%$ & $27,0 \%$ & $16,0 \%$ \\
\hline $5-10$ & $14,1 \%$ & $10,0 \%$ & $13,9 \%$ & $19,6 \%$ & $26,9 \%$ & $13,3 \%$ \\
\hline $10+$ & $8,2 \%$ & $72,8 \%$ & $43,1 \%$ & $75,6 \%$ & $46,1 \%$ & $70,7 \%$ \\
\hline
\end{tabular}

Source: authors' own calculations based on data from European statistics (EUROSTAT, 2011) and Statistical Office of the Republic of Serbia (2013b).

The data in Table 2 clearly show that small agricultural holdings prevail in Serbia. Specifically, $77,7 \%$ of the agricultural holdings own property of less than 5 ha, while only $8,2 \%$ own property greater than/equal to $10 \mathrm{ha}$. The situation is even worse if we take into account that approximately $58 \%$ of private land covers an area smaller than 3 ha. In contrast, in Denmark, only $4.8 \%$ of agricultural holdings own property less than 5 ha in size and many as $75.6 \%$ own property greater than/equal to 10 ha. In Graph 2, a comparative graphical representation of the average size of the holdings in Serbia and certain European 
countries is shown.

Graph 2. Average area per holding (in ha), (2010)

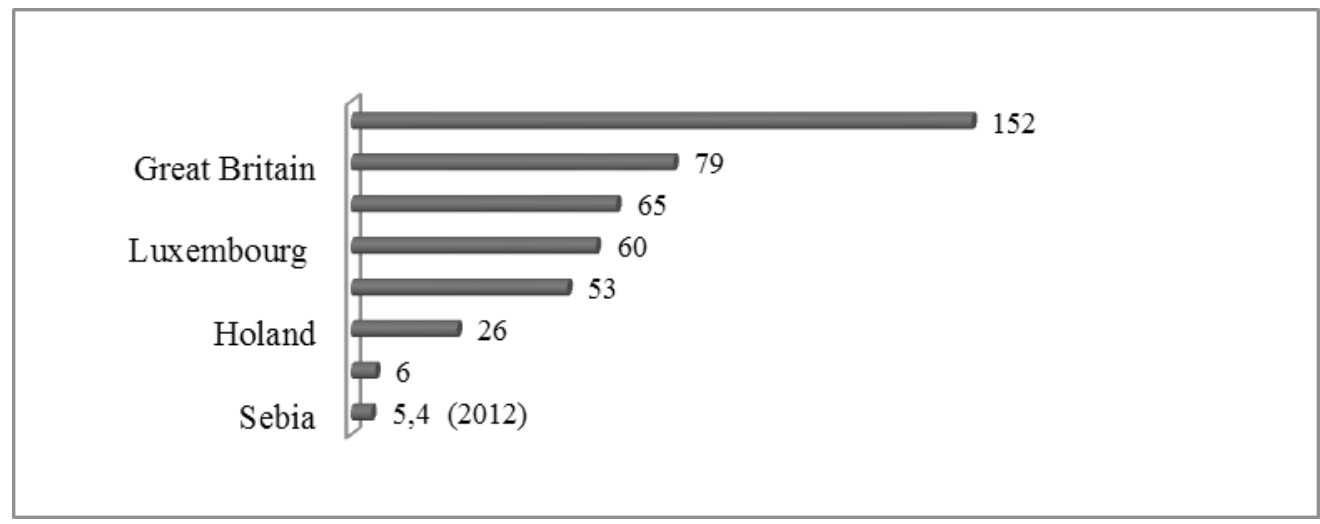

Source: authors' figure based on data from EUROSTAT (2011) and the Statistical Office of the Republic of Serbia (2013b).

The average area per holding in Serbia is about 5,4 ha but, for example, in Denmark it is 65 ha, and 152 ha in the Czech Republic. The experience of developed European agriculture shows that only large holdings provide quality production and profit. Large property has greater possibilities for improving production technology, integrated and biological protection of crops and products, more rational and efficient use of machinery, efficient irrigation, the gathering together and collaboration of the best research and professional personnel. Unfavourable ownership structure causes, in many ways, low labour productivity in agriculture. Zekić and Popović (2010) suggest that the land and labour productivity ${ }^{3}$ in Serbia were significantly lower than in the EU countries.

In our conditions, within the fragmented ownership structure, three groups of problems appear (Pejanović, Tica, 2005):

- Modern technology and machinery cannot adequately and rationally be used on small holdings, nor can technological progress be achieved, which is the backbone of modern agricultural economy;

- Income in small production cannot follow the trend of income at the national level, which results in the abandonment of rural areas and agriculture, and the depopulation of villages;

- The low productivity of small production contributes to the rising prices of agricultural products, and it is difficult to keep up with the competition from developed countries.

In other words, our farms are so fragmented and weakened, as well as unprofessional, that it leads us to the question of whether there is any possibility of higher, economically more rational, production. Given the Serbian aspirations to join the European Union (EU), more

3 Labor productivity measured by the volume of agricultural production per active farmer. 
profound changes in land policy are needed. Without a concentration of small holdings and the creation of large agricultural areas, Serbia does not have much chance for success in the Common Agricultural Policy (CAP) of the EU.

\section{The Inefficiency of the Agricultural and Economic Policy}

Former Serbian agricultural policy is flawed and inadequate. Its basic features of the past decade are: instability, inconsistency, minimal protection of the domestic market and the lack of financial support that is not tied to the structural adjustments.

The instability and inconsistency of the agricultural policy is easily noticeable when we consider the changes made in the past decade, which can be divided into four phases. In the first phase (2001-2003), agricultural policy was oriented towards measures of price support for certain cultures (soybean, sunflower, sugar beet and wheat) in the absence of other measures. In the second phase (2004-2006), the price support measures were repealed and go to support investment and rural development. The third phase (2007-2011) was characterized by incentive payments per cultivated area and livestock unit. The fourth phase (2012- the present) is a transition from the subsidies per hectare to subsidies per agricultural product in terms of quantity, which is not in accordance with the existing and future CAP. The lack of consistency in the design and implementation of agricultural policy in the past has resulted in a reduction of investment in agriculture and non-market spill over profit among participants in the market chain. Therefore, the adoption of the National Program for Agriculture is an important step towards the improvement of agricultural policy, as it will contribute to its predictability and create the basis for short and medium term production planning (MAFWM, 2012).

Agro-interventionism is a fact of modern society, despite some attempts to prove the existence of full economic liberalism (Garmann, 2014; Marković, Marković, 2014). "In practice, on the contrary, no country wants to rely entirely on the spontaneous development of agriculture and the free and uncontrolled import of food, but tries to use a system of protection and intervention to achieve its development goals and ensure maximum food assurance" (Pejanović, Tica, 2005, p. 92). However, in Serbia, the prices of agricultural and food products were completely liberalized ten years ago (Figure 3), and there are no protective prices for even basic agricultural and food products. According to Ševarlić (2011), subsidies vary based destination, amount and users. They are approved in the same amount for all classes of soil, favouring the lowlands. Although there have been attempts to reduce subsidies for the bigger registered holdings, first with the limit that only 10 ha will be subsidized, they are still retained up to 100 ha. In addition, there are also regional disparities between subsidies per ha, as the Autonomous Province of Vojvodina is the biggest recipient of subsidies with $76 \%$, in comparison with Central Serbia which is given only $24 \%$ of the total subsidies. When it comes to levies and tariffs, they ensure a seasonal effect for some products as well as weak protection from imports at dumping prices. With the Interim Trade Agreement between Serbia and the EU, which has been applied to agricultural products since 2009, the protection of the national market has been reduced to a minimum. 
Graph 3. The liberalizing of tariffs for agro-food products in Serbia

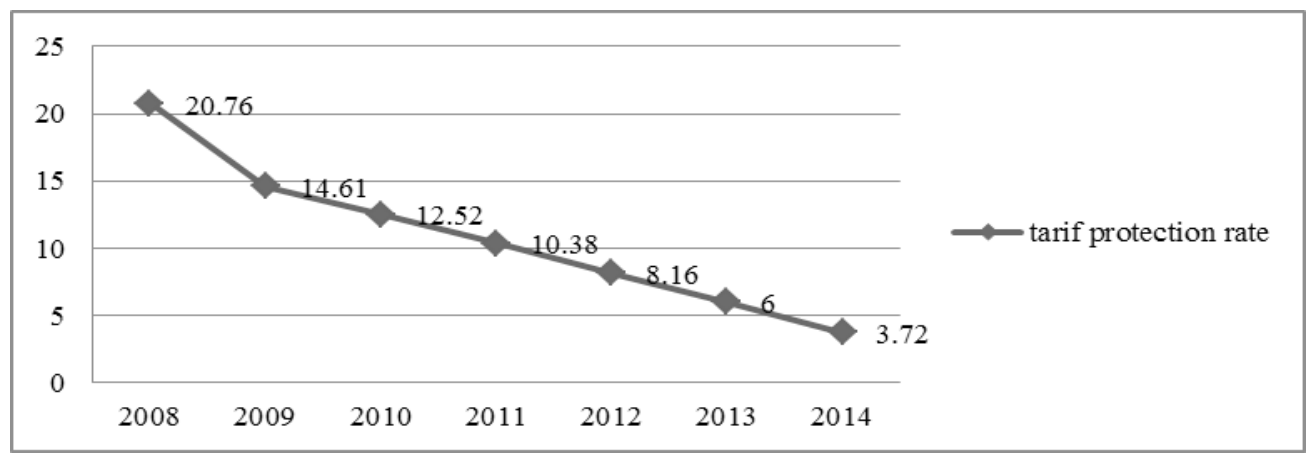

Source: Bugarin (2012).

One of the biggest problems facing Serbian agriculture is the modest agricultural budget. Paradoxically, over the past three years, the state has earmarked the least amount of money for the area where we find the largest increase in production and exports. Agricultural economics is, therefore, suffering extensive loss, because the manufacturers will not, in the long run, be able to compete with their competitors in a region which receive significantly larger subsides. In Figure 4, a downward trend in the relative share of agricultural in the overall budget of the Republic of Serbia, with a sharp decline in participation from 2009-2011, can be seen. In contrast, the contribution of agriculture towards the Gross Domestic Product (GDP) is significantly higher.

Graph 4. The share of agricultural in the overall budget of the Republic of Serbia (2004-2012)

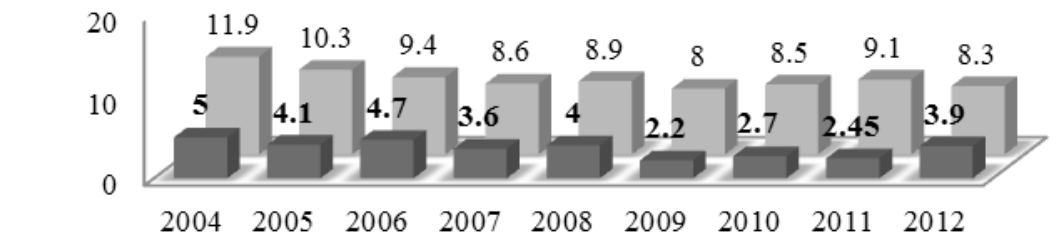

m share of agriculture in total budget $\quad$ share of agriculture in total GDP

Source: authors' own figure based on data from Ministry of Finance and Economy - Law of budget for certain years and the Statistical Office of the Republic of Serbia (2009, 2011, 2012, 2013c).

Along with inadequate agricultural policy, the slow development of institutions and legislative support further hinders the implementation of transition reforms. The Directorate for Commodity Reserves, advisory services and water management organizations that still operate as state-owned enterprises, the lack of implementation of the reform of scientific 
institutions which offer support to our agricultural department are just some of the unfinished projects involved in establishing an institutional framework for the development of agriculture. Cooperatives associations, chambers of commerce and professional organizations are not, although they should be, the leaders of the development of agriculture, because they are incapable of conducting their own internal reforms. The agricultural legislation has yet not been completed, and it is difficult to apply as well. Although in the year of 2009, 15 Agriculture Acts were issued, it appears that this set of laws was hastily passed in order to comply with the formal requirements of the EU. Problems are expected in the implementation. In addition, there is a lack of other important laws such as the Law on Cooperatives.

\section{The unsuccessful privatization process in agriculture}

Implementation of the privatization process did not work as expected and desired. A long process of demarcation between the state and socially-owned land, property and legal issues of ownership, obstructions on the part of those who do not want the privatization to succeed, the long process of preparation for privatization, frequent revisions and reviews of some of the privatization processes which had already been carried out significantly slowed down this process. "The basic principles of privatization are insufficiently respected, especially the principle of transparency which has caused great damage to many prominent agricultural companies" (Pejanović, Tica, 2004, p. 9).

Until 2011, 153 agricultural enterprises, farms and agricultural combines were sold for about 280 million euros (at auction or by tender). Of these, 38 privatization agreements were terminated (Agrobiznis, 2011). The privatization of agricultural enterprises in Serbia was premature because of no appropriate laws, which led to the collapse of large agricultural conglomerates. During privatization, with the help of the amended Law on Agricultural Land, large agricultural conglomerates were broken down, as organizational and technological complexes, since it was socially-owned land that was undergoing the privatization process, while the state-owned land remained in state ownership to be used free of charge by a buyer (Djekić, Vučić, 2002). It was only after the year 2006 that it was put up for auction or leased. The co-operative sector is completely excluded from the process of transitional reforms, since due to the untimely legislation, it was mostly subject to takeovers in bankruptcy. In the companies that have been privatized, about 65,000 people have lost their jobs, which puts agriculture in the infamous second place, following the textile industry, in terms of the number of workers who lost their jobs in the transition process. It is clear that this situation would not have happened if the principle that guarantees the free enterprise and the rights of the employees had been adhered to.

So far, the process of privatization in agriculture has resulted in low levels of foreign investments. The net inflow of foreign direct investments (FDI) in the agricultural sector of Serbia is extremely modest. Unlike the other sectors of the economy, agriculture is not attractive for FDI activity, considering that in the structure of FDI in Serbia, agriculture participated with $0.4 \%$ in 2011 , and $0.3 \%$ in 2012 (Table 3). 
Table 3. FDI in Agriculture of the Republic of Serbia (2004-2012)

\begin{tabular}{|l|r|r|r|r|r|r|r|r|r|}
\hline \multicolumn{1}{|c|}{ Indicator } & $\mathbf{2 0 0 4}$ & $\mathbf{2 0 0 5}$ & $\mathbf{2 0 0 6}$ & $\mathbf{2 0 0 7}$ & $\mathbf{2 0 0 8}$ & $\mathbf{2 0 0 9}$ & $\mathbf{2 0 1 0}$ & $\mathbf{2 0 1 1}$ & $\mathbf{2 0 1 2}$ \\
\hline $\begin{array}{l}\text { FDI (in 000 } \\
\text { USD) }\end{array}$ & 9.449 & 11.578 & 11.345 & 20.970 & 57.908 & 29.288 & 14.556 & 13.657 & 1.030 \\
\hline $\begin{array}{l}\text { Share in total } \\
\text { investments }\end{array}$ & $1,0 \%$ & $0,7 \%$ & $0,2 \%$ & $0,5 \%$ & $1,6 \%$ & $1,2 \%$ & $1,0 \%$ & $0,4 \%$ & $0,3 \%$ \\
\hline
\end{tabular}

Source: Jovović et al., 2014.

\section{Conclusion and recommendations}

During the transition process in the Republic of Serbia, no significant changes in the economic structure actually took place. Since the beginning of the 21 st century, the greatest contribution of agriculture to the gross domestic product is still high, despite the GDP decrease. Agriculture has a high stake in all of the macro-economic aggregates of the Republic of Serbia. This can be ascribed to rich natural resources on the one hand, and the slower process of structural reform of the other economy sectors on the other. Based on the extent and structure of the available agricultural land, Serbia is one of the countries with favourable land resources, which is the result of a great heterogeneity of the geological structure, climate, vegetation and micro fauna. Even though over the last few decades the process of vacating rural areas has intensified, the agricultural population still makes up a significant portion of the overall national population. The only problem in terms of agricultural labour is the unfavourable age and education structure.

The ownership structure of the agricultural households is characterized by the dominance of small-size agricultural households. In comparison to the neighbouring countries, in Serbia, agricultural households which do not exceed 5 ha are predominant. In addition to the fragmentation of the plots of land, the other obstacles to a more efficient use of the land potential include the lack of infrastructure, the lack of proper credit, social insecurity that the property owners are subject to and the incomplete restitution process. One of the consequences of this unfavourable agricultural structure is primarily the outdated machinery and equipment that is available to the homeowners, which contributes to the increase of the production expenses.

The previous decade was marked by significant annual fluctuations of the volume of agricultural production. The main reason for this is the inadequate agricultural and economic policy, even though we need to mention the cyclical occurrences of extreme weather, as well as the negative effects of the world economic crisis. The unstable agricultural policy is characterized by sharp turns in policy and incentive mechanisms. The first radical turn referred to the distancing from the agricultural interventionism, which led to the minimal protection of the national market. The liberalization of the customs tariffs and ineffective subsidy policy led to a decrease in the competitiveness of local agricultural production and increased the dissolution in the small agricultural households. The greatest weakness of the agricultural and economic policy is certainly the insufficient financial support given to 
agriculture, considering the fact that for a long period of time the agricultural budget has not exceeded $5 \%$ of the overall budget size. Such an agricultural policy has been accompanied by institutional changes which in this sector took place very slowly, and without any continuity. What also added to the performance of the transitional reforms was the unsuccessful process of privatization, which resulted in the dissolution of large agricultural combines and the low level of foreign investment.

Starting with the aforementioned problems in agriculture, it is possible to provide several recommendations for strengthening the agricultural sectors and the development of an agriculture which is focused on export. First, the state should change its agricultural policy and ensure better utilization of resources in agricultural and food production. It is necessary to make domestic agricultural policy measures compatible with EU measures in order to avoid harmful consequences caused by the subsequent obligations of EU membership. This means creating measures that are compatible with those existing in the EU, while anticipating the future of the CAP measures. In addition, we need institutional reforms which would revive the existing and build the missing parts of our institutional structures, and enable an effective application of defence policies. In this case, the doubling of agricultural production and exports would be quick to follow.

One of the priorities of the new agricultural policy should be directed toward the consolidation of property. This goal also cannot be achieved without a comprehensive national program and adhering to its implementation. It, first of all, refers to the arrangement of the cadastre and commutation of cultivable areas at the expense of the state. The establishment of stimulus funds for purchasing land from elderly and non-agricultural households and their consolidation is one of the possible options, as well as insisting on amending the Law on inheritance; therefore, priority in acquiring land should be given to those who work and live from it.

Economic policy should support the implementation of agricultural policy, primarily by increasing the agricultural budget in order to stop the negative trends and to revive agriculture and villages. Also, there is a necessity for a selective approach to budget spending, with clearly defined investment criteria in well-designed and profitable projects, such as irrigation, new techniques and technology, education, research and development, and the like. As a part of foreign trade policy, it is very important to reduce customs to a reasonable level.

At the micro level, it is necessary to restructure the agro-economy units and make them more competitive. A very professional and high quality privatization management process must be provided, as well as complete transparency of work and continuous parliamentary control of the institutions that implement it, in order to avoid dubious privatization processes. Lastly, a creation of a long-term and stable agricultural investment climate is crucial in order to attain a higher inflow of FDI in Serbian agriculture, which is considered to be the responsibility of the state and its institutions. 


\section{References}

1. Agrobiznis (2011): Loša privatizacija u poljoprivredi, e-magazin Agrobiznis, available at: www.agrobiznis.biz/index.php?n=1\&idn=734 retrieved at: 10.02.2014.

2. Bugarin, M. (2012): Bitka za tržište: Kako što bolje iskoristiti proizvodne i izvozne potencijale poljoprivrede i prehrambene industrije Srbije, II Poljoprivredni forum "Hrana za Evropu", Subotica, Ekonomski institut, Beograd, available at: http://www. ecinst.org.rs/sites/default/files/prezentacije/poljoprivredni/Drugi-poljoprivredniforum-Prezentacija-govornika-Vojislav-Stankovic.pdf

3. Djekić, S., Vučić, S. (2002): Problems in Serbian agriculture in the process of transition, Facta Universitatis, vol. 1, no. 10, pp. 7-13.

4. EUROSTAT (2011): Agriculture census 2010 - Provisional results, available at: http://ec.europa.eu/eurostat/statistics-explained/index.php/File:Agricultural_census_2010 provisional results corrected.xls retrieved at: 20.11.2013.

5. FAOSTAT, World agricultural statistics data base, Population - Annual time series, available at: $\mathrm{http} / / /$ faostat.fao.org/site/550/default.aspx\#ancor retrieved at: 02.02.2014.

6. Garmann, S. (2014): Does globalization influence protectionism? Empirical evidence from agricultural support, Food Policy, vol. 49, part 1, pp. 281-293.

7. Jovović, D., Stojadinović Jovanović S., Dašić, B. (2014): Agricultural trade and financing through FDI, Economics of Agriculture, vol. 61, no. 2., pp. 455-469.

8. Marković, I., Marković, M. (2014): Agricultural protectionism of the European Union in the conditions of international trade liberalization, Economics of Agriculture, vol. 61, no. 2, pp. 423-440.

9. Maslac, T. (2013): Serbia - Exporter Guide, Annual Report, Gain Report Number: 1310, Global Agricultural Information Network, USDA Foreign Agricultural Service, pp. 1-19.

10. Ministry of Agriculture, Forestry and Water Management of the Republic of Serbia (MAFWM), (2012): National program for agriculture 2010-2013, available at: http:// uap.gov.rs/wp-content/uploads/2011/02/nacionalni-program-za-poljoprivredu1.pdf

11. Ministry of Agriculture, Forestry and Water Management of the Republic of Serbia (MAFWM), (2014): Agriculture and rural development strategy of the Republic of Serbia for the period 2014-2024., Official Gazette of Republic of Serbia, no. 85/2014.

12.Ministry of Finance and Economy of the Republic of Serbia, Series of Budget Lows 2004-2012., Treasury, Belgrade.

13. Pejanović, R., Tica, N. (2005): Agrarni problem u procesu tranzicije Republike Srbije, Letopis naučnih radova Poljoprivrenog fakulteta, vol. 29, no.1, pp. 210-221.

14.Pejanović, R., Tica, N. (2004): Tranzicione reforme u agroprivredi Republike Srbije, Letopis naučnih radova Poljoprivrednog fakulteta, vol. 28, no. 1, pp. 85-96.

15. Petrović, M. M. (2005): Livestock production in Serbia on way to European Union, 
Biotechnology in Animal Husbandry, vol. 21, no. 5-6, pp. 1-8.

16. Petrović, M. M., Petrović, M. P., Petrović, M., Aleksić, S., Ostojić Andrić, D., Pantelić, V., Novaković, Ž. (2011): How to increase production of beef, lamb and pork in Serbia for domestic market and export, Biotechnology in Animal Husbandry, vol. 27, no. 3, pp. 293-303.

17.Ševarlic, M. (2011): Agroprivreda Srbije - između šansi i realnosti na evropskom tržištu hrane, I Poljoprivredni forum "Hrana za Evropu", Subotica, Ekonomski institut, Beograd, available at: www.ecinst.org.rs/sites/default/files/prezentacije/3. prezentacija govornika miladin sevrlic.pdf

18. Statistical Office of the Republic of Serbia (2009): GDP in Republic of Serbia 20042007, Statistics of national accounts, Report HP30, no. 037, SORS, Belgrade.

19. Statistical Office of the Republic of Serbia (2010): Agriculture 2009, Bulletin 523, SORS Belgrade, available at: http://webrzs.stat.gov.rs/WebSite/repository/ documents/00/00/05/26/PoljBilten2009.pdf

20. Statistical Office of the Republic of Serbia (2011): GDP in Republic of Serbia 20062009, Statistics of national accounts, Report HP30, no. 54, SORS, Belgrade.

21. Statistical Office of the Republic of Serbia (2012): GDP in Republic of Serbia 20072010, Statistics of national accounts, Report HP30, no. 80, SORS, Belgrade.

22. Statistical Office of the Republic of Serbia (2013): Statistical Yearbook of the Republic of Serbia 2013, Chapter 9, pp. 209-234, SORS, Belgrade, available at: http://webrzs.stat.gov.rs/WebSite/repository/documents/00/01/17/60/09_Poljoprivreda.pdf

23. Statistical Office of the Republic of Serbia (2013a): Statistical pocketbook of the Republic of Serbia 2013, Belgrade, SORS, Belgrade, available at: http://webrzs.stat. gov.rs/WebSite/repository/documents/00/00/98/07/Statisticki kalendar_RS 2013.zip

24. Statistical Office of the Republic of Serbia, (2013b): Census of Agriculture 2012, Agriculture in the Republic of Serbia, SORS, Belgrade.

25. Statistical Office of the Republic of Serbia (2013c): GDP in Republic of Serbia 2012, Statistics of national accounts, Report HP30, no. 347, SORS, Belgrade.

26.Zekic, S., Popovic, R. (2010): Evolution, state and perspectives of Serbian agriculture within EU integrations, AAB Bioflux, vol. 2, no. 2, pp. 98-110. 


\title{
STANJE I PROBLEMI POLJOPRIVREDE SRBIJE
}

\author{
Semir Vehapi ${ }^{4}$, Zenaida Šabotic ${ }^{5}$
}

\begin{abstract}
Rezime
Moderna poljoprivreda podrazumeva proces izgradnje nove privredne delatnostizasnovane na efikasnosti, konkurentnosti, intenzivnosti $i$ tržišnosti. Proces prelaska poljoprivrede Srbije na tržišne uslove poslovanja je dug i otežan. U radu autori identifikuju najznačajnije problem ovog procesa: nepovoljna posedovna struktura i niska produktivnost, neefikasna agrarna i ekonomska politika, spor razvoj institucija podrške i zakonodavnog okvira $i$ neuspešna privatizacija i restruktuiranje poljoprivrednih preduzeća i kombinata. Reč je o nizu hroničnih problema koji ozbiljno ugrožavaju razvoj poljoprivrede $i$ otežavaju sprovođenje tranzicionih reformi. Pored toga, autori daju predlog mera i akcija za ostvarivanje tranzicionog zaokreta u ovoj, za Srbiju strateški važnoj privrednoj grani.
\end{abstract}

Ključne reči: poljoprivreda, posedovna struktura, agrarna politika, privatizacija, Republika Srbija.

4 Asistent, Državni univerzitet u Novom Pazaru, Departman za Ekonomske nauke (kabinet br. 23), Vuka Karadžića bb, 36300 Novi Pazar, Republika Srbija, Telefon: +381 638618 381, E-mail: semir.vehapi@gmail.com

5 Asistent, Državni univerzitet u Novom Pazaru, Departman za Ekonomske nauke (kabinet br. 23), Vuka Karadžića bb, 36300 Novi Pazar, Republika Srbija, Telefon: +381 63 506146, E-mail: zenaida.šabotić@gmail.com

EP 2015 (62) 1 (245-257) 